Pathophysiology

Haemostasis

and Thrombosis

\title{
Therapeutic Options in Patients with DIC and Cancer
}

\author{
Marcel Levi \\ Department of Medicine, Academic Medical Center, University of Amsterdam, The Netherlands
}

\section{Introduction}

Malignant disease may be complicated by the occurrence of disseminated intravascular coagulation (DIC) in $7-20 \%$ of cases [1]. In particular, adenocarcinoma and hematological malignancies are relatively frequently complicated by DIC $[2,3]$. Clinically, DIC in cancer has in general a less fulminant presentation than the types of DIC complicating sepsis and trauma. A more gradual, but also more chronic, systemic activation of coagulation can proceed subclinically [4]. The manifestation of DIC may be merely thrombotic, with obstruction of the microvasculature of various organs but more frequently venous thromboembolism occurs [5]. Although the pathogenesis of DIC in patients with cancer follows similar pathways as in other underlying causes of DIC, some pathogenetic features are quite specific for malignant diseases [6, 7]. In the following, a brief overview of the pathogenesis of DIC in cancer will be given, with an emphasis of those pathways that provide a point of impact for (supportive) treatment strategies in patients with cancer and DIC.

\section{Pathogenesis of DIC in Cancer}

Malignant cells can express different procoagulant molecules including tissue factor (TF), which assembles with factor VII(a) to activate factors IX and X, and subsequently generates thrombin, which converts fibrinogen into fibrin, activates platelets and further amplifies the coagulation cascade $[8,9]$. Previous studies have shown the occurrence of functionally active tissue factor in vascular endothelial cells as well as tumor cells in breast cancer, while not appearing in material from patients with benign fibrocystic breast disease [10]. It should be noted that the role of tissue factor in pathophysiology is only partly understood as yet. Independent from its clotting cofactor function tissue factor appears to be involved in tumor metastasis and angiogenesis, factors that may directly influence the course of malignancy and affect the occurrence of thrombosis [11]. Another, more cancer-specific procoagulant that is expressed by tumor cells is cancer procoagulant (CP), a cysteine protease with factor $\mathrm{X}$ activating properties [12]. Cancer procoagulant is an endopeptidase that is found in extracts on neoplastic cells but also in the plasma of patients with solid tumors. The exact role of $\mathrm{CP}$ in the pathogenesis of cancer-related DIC is unclear.

Another factor in the procoagulant state associated with cancer may be a downregulation of physiological anticoagulant pathways [13]. Experimental studies have shown that anticoagulant concentrates may affect coagulation but also tumor growth and metastasis formation [14]. Also, a marked increase in resistance towards activated protein $\mathrm{C}$ was observed in patients with cancer [15]. Lastly, a disbalance between tissue factor expression and its main inhibitor, tissue factor pathway inhibitor (TFPI) may also

\begin{tabular}{ll}
\hline KARGER & (c) 2003 S. Karger AG, Basel \\
Fax $+41613061234-8832 / 03 / 0337-0046 \$ 19.50 / 0$ \\
$\begin{array}{l}\text { E-Mail karger@karger.ch } \\
\text { www.karger.com }\end{array}$ & $\begin{array}{l}\text { Accessible online at: } \\
\text { www.karger.com/journals/pht }\end{array}$
\end{tabular}


affect the procoagulant state in cancer [16]. In addition, another mechanisms by which tumor cells may contribute to the pathogenesis of DIC is by expressing fibrinolytic proteins [17]. Despite the ability of many malignant cells to express plasminogen activators, such as urokinase-type plasminogen activator (u-PA) and tissue-type plasminogen activator (t-PA), most tumors induce a hypofibrinolytic state. Since DIC is commonly characterized by a shut-down of the fibrinolytic system (mostly due to high levels of the fibrinolytic inhibitor PAI-1) this may represent an alternative mechanism for the development of DIC in cancer.

\section{Potential Therapeutic Consequences}

In view of the central role of tissue factor in the pathogenesis of the procoagulant state in cancer, therapies directed against tissue factor activity might be effective. In experimental settings the efficacy of TFPI in blocking tissue factor-mediated thrombin generation, but also on tumor seeding and growth, has been demonstrated [14]. Another point of impact might be the activated protein $\mathrm{C}$ pathway. Activated protein $\mathrm{C}$ is a pivotal inhibitor of coagulation but has in addition a number of other effects in the microvasculature, including a modulating effect on inflammation [18]. In cancer patients there is a remarkable upregulation of the endothelial protein $\mathrm{C}$ receptor (EPCR), which plays a role in these effects of activated protein $\mathrm{C}$ [19]. Treatment targeted at the protein $C$ system, either by infusion of recombinant activated protein $\mathrm{C}$ or by modulating the expression or binding capacity of EPCR might prove beneficial in containing the activation of coagulation in cancer, and may have additional effects on the tumor and its dissemination. Adequate clinical studies with either TFPI or activated protein $C$ in patients with cancer are not available at this time and are required to assess the role of modulation of coagulation in patients with malignant disease.

\section{References}

1 Levi M: Cancer and DIC. Haemostasis 2001; 31(suppl 1):47-48.

2 Sallah S, Wan JY, Nguyen NP, Hanrahan LR, Sigounas G: Disseminated intravascular coagulation in solid tumors: Clinical and pathological study. Thromb Haemost 2001;86:828-833.

3 Sarris AH, Kempin S, Berman E, Michaeli J, Little C, Andreeff M, Gee T, Straus D, Gansbacher B, Filippa D: High incidence of disseminated intravascular coagulation during remission induction of adult patients with acute lymphoblastic leukemia. Blood 1992;79:1305-1310.

4 Francis JL, Biggerstaff J, Amirkhosravi A: Hemostasis and malignancy. Semin Thromb Hemost 1998;24:93-109.

5 Colman RW, Rubin RN: Disseminated intravascular coagulation due to malignancy. Seminars in Oncology 1990;17:172-186.

6 Levi M, ten Cate H: Disseminated intravascular coagulation. N Engl J Med 1999;341:586-592.

7 Rickles FR, Falanga A: Molecular basis for the relationship between thrombosis and cancer. Thromb Res 2001;102:V215-V224.
8 Levi M, van Gorp E, ten Cate H: Disseminated intravascular coagulation; in Handin RI, Lux SE, Stossel TP (eds): Blood: Pinciples and Practice of Hematology. Philadelphia, J.B. Lippingcott, 2002.

9 Donati MB, Falanga A: Pathogenetic mechanisms of thrombosis in malignancy. Acta Haematol 2001;106:18-24.

10 Contrino J, Hair G, Kreutzer DL, Rickles FR: In situ detection of tissue factor in vascular endothelial cells: Correlation with the malignant phenotype of human breast disease. Nature Medicine 1996;2:209-215.

11 Bromberg ME, Konigsberg WH, Madison JF, Pawashe A, Garen A: Tissue factor promotes melanoma metastasis by a pathway independent of blood coagulation. Proc Natl Acad Sci USA 1995;92:8205-8209.

12 Donati MB: Cancer and thrombosis: From Phlegmasia alba dolens to transgenic mice. Thromb Haemost 1995;74:278-281.

13 Sampson MT, Kakkar AK: Coagulation proteases and human cancer. Biochem Soc Trans 2002;30: 201-207.
14 Francis JL, Amirkhosravi A: Effect of antihemostatic agents on experimental tumor dissemination. Semin Thromb Hemost 2002;28:29-38.

15 Nijziel MR, van Oerle R, Christella $M$, Thomassen LG, van Pampus EC, Hamulyak K, Tans G, Rosing J: Acquired resistance to activated protein $\mathrm{C}$ in breast cancer patients. Br J Haematol 2003;120:117-122.

16 Iversen N, Lindahl AK, Abildgaard U: Elevated TFPI in malignant disease: Relation to cancer type and hypercoagulation. Br J Haematol 1998;102: 889-895.

17 Falanga A: Mechanisms of hypercoagulation in malignancy and during chemotherapy. Haemostasis 1998;28(suppl 3):50-60.

18 Levi M, ten Cate H, van Der PT: Endothelium: Interface between coagulation and inflammation. Crit Care Med 2002;30:S220-S224.

19 Tsuneyoshi N, Fukudome K, Horiguchi S, Ye X, Matsuzaki M, Toi M, Suzuki K, Kimoto M: Expression and anticoagulant function of the endothelial cell protein $\mathrm{C}$ receptor (EPCR) in cancer cell lines. Thromb Haemost 2001;85:356-361. 